\title{
Research on Training Mode of Innovative and Entrepreneurial Education in Chinese Universities
}

\author{
Yanhong Sun ${ }^{\mathrm{a}}$, Xinxin Gao ${ }^{\mathrm{b}}$ and Lidan Fan ${ }^{\mathrm{*}}$ \\ College of Mechanical Engineering, Jilin Engineering Normal University, Changchun 130052, China \\ a343175460@qq.com, ${ }^{b} 1551109305 @ q q . c o m,{ }^{c} 574024123 @ q q . c o m$ \\ *The corresponding author
}

Keywords: Universities; Innovative and entrepreneurial education; Talent training model

\begin{abstract}
The Innovative and Entrepreneurial education embodies the economic progress and social development of the fundamental requirements for talents. Universities shoulder important responsibility of cultivating high-quality talents, through the analysis of the status quo and development trend of the universities' IE education in our country, from several aspects including IE education personnel training mechanism, reforming the teaching method and the examination form, strengthening " school-enterprise" cooperation, talent training mode of practice teaching based on "production-education" integration, making full use of the second training class. The main ways are put forward to realize the cultivation of talents in Chinese universities' IE education.
\end{abstract}

\section{Introduction}

In recent years, with the rapid development of Chinese economy, the demand for innovative and entrepreneurial(Referred to as "IE") talents is becoming increasingly urgent. To cultivate high-quality talents with strong sense of innovation who can meet the social needs and push forward the development of social economy has become an important responsibility of university education[1]. At the same time, in recent years, the employment situation of students is worrying and the employment rate is relatively low. College students' self employment is a way to turn to employment. However, our college students' independent entrepreneurial ability needs to be strengthened, and schools need to actively guide [2]. The traditional way of education in China is based on teachers' knowledge, which is not conducive to the cultivation of "innovative and entrepreneurial" talents. There is still a big gap between the innovative and entrepreneurial talent training ability of universities and the objective requirements of social and economic development at present[3]. In 2014, General Secretary Xi put forward the idea of "innovative country", Prime minister Li put forward that "mass entrepreneurship and innovation", they are a major strategic decision that is related to the overall situation of socialist modernization. Therefore, our country urgently needs education system to cultivate a large number of high-quality innovative and entrepreneurial talents. It is very necessary to explore innovative talents in Universities.

\section{Current Situation Analysis of IE Education in Chinese Universities}

Current situation of IE education is analyzed, shown in Fig. 1. Although the school IE education has made great progress over the years, there is still a big gap compared with foreign universities [4].

No Real Awareness of the Significance of Strengthening IE Education. At present, many universities are busy expanding, the school's own resources are limited, not enough funds and energy are used in the students' IE education. Many teachers are accustomed to the original teaching methods, leading to the level of IE education in universities is stagnant. Most students only care about whether they can get a satisfactory job if they pass the exam. The neglect of IE education by schools, teachers and students has seriously affected the level of innovation and entrepreneurship training of universities [5].

Not Form The Training Mode of IE Talents Adapted to Social Development. Although schools have implemented many policies and systems that are conducive to the cultivation of 
innovative and entrepreneurial talents, they are often isolated from each other and have not formed a reasonable system of [6]. Although the national school, in order to improve the students' ability to hold many "Challenge Cup "entrepreneurial activity, but the students did not understand the real meaning of the game, just to participate in the competition, to get awards, these activities did not achieve the purpose of the original intention of [7].

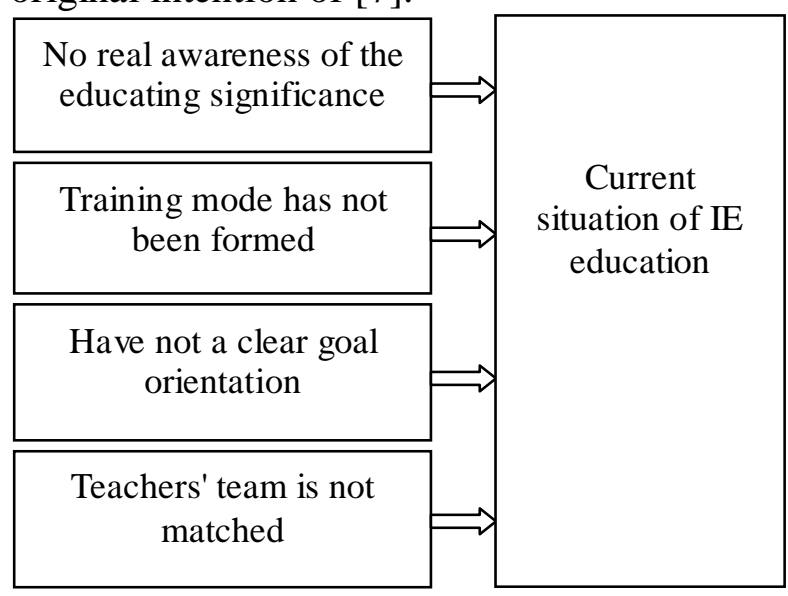

Figure1. Current situation of IE education

Have No A Clear IE Education Goal Orientation. Although the IE education has attracted wide attention from all walks of life, however, due to the lack of a clear goal orientation, the level of IE education in universities has been improving slowly. First of all, the school is not included in the IE education of teacher evaluation system, teachers' salary increase and promotion is not linked with the innovation ability of teachers, so not evaluation system of the existing teachers to improve the incentive effect of formation of IE education. Secondly, in terms of students, school assessment of students often examines students' mastery of teachers' content, and fails to evaluate students' innovative and entrepreneurial ability, which greatly weakens students' initiative to improve their innovative and entrepreneurial abilities.

The Current Level of Teachers' team Is Not Matched with The Requirements of IE Education. Teachers in universities in China often have a high degree of education, but they lack the actual experience of entrepreneurship and company management. Many teachers in foreign countries often have rich practical experience. They have experience in venture and investment, and are very familiar with work. Therefore, the level of teaching staff has restricted the development of innovation education in Chinese universities.

\section{IE Development Trend in Chinese Universities}

With the transformation of applied undergraduate colleges, the reform of vocational education will become an effective combination with IE education. Innovative universities with distinctive characteristics will start to emerge, and the IE demonstration is promoted to the other schools.

The reform of the training program for professional talents in universities is faced with the reform. The IE education of industry and management will become the focus of all schools.

The industry began to integrate the production and education, the school enterprise cooperation to realize the industrial transformation and upgrading.

The investment circle has begun to pay attention to the innovation and venture capital of universities, especially the investment in the early venture project of college students.

The practice teaching of college management and economic majors will integrate organically with IE practice teaching, and provide full life cycle IE practice teaching services for all students in the whole school.

The transformation of scientific research achievements in universities will become a new bright spot for innovation and entrepreneurship. Universities begin to explore a new model of "scientific research + teaching + competition + entrepreneurship + employment". 
The era of IE education, more and more enterprises will enter college market, strategic partner colleges face many choices, and need cooperation of enterprises with " System Planning + Platform Construction + Teaching Contents + Teacher Training + Environment Construction + Talent Service".

\section{Main Realizing Ways of IE Talents Training in Universities in China}

Establishing The Training Mechanism of Creative and Entrepreneurial Education. The type of new structural adjustment to establish a training system of discipline structure and employment oriented demand oriented economic development of local talent, the establishment of cooperative education school, the establishment of cross department, interdisciplinary and multi-disciplinary cross fostering innovation and entrepreneurship to the new mechanism; Strengthen the students' self-learning and self-development mechanism. We should respect students' choices, interests and hobbies, expand students' learning autonomy, cultivate students' independent learning consciousness and ability, and achieve flexible educational system, split training and hierarchical teaching.

Reform to Teaching Methods to take the Teaching Mode of Flipped Classroom, Teacher Centered and Student Centered, focusing on Cultivating Students' Innovative Thinking. With the IE educational ideas, the content and methods of teaching, the content and methods of assessment and the comprehensive innovation of teaching technology are promoted. In accordance with the transformation of the development needs, to carry out project teaching, case teaching, heuristic, discussion, participatory teaching, realize the combination from the cramming teaching to impart knowledge and innovation, and practice, teacher-student interaction, with emphasis on the assessment of teaching benefits teachers as well as students[8]. Content and evaluation of knowledge memory standard into examination content and evaluation as the main body the standard of ability, quality and innovation factors for students, to stimulate students' innovative consciousness, innovative desire, passion for innovation, the "double" spirit and ability in teaching evaluation index system.

Strengthening the Practice Teaching Model of "School-enterprise" Synergy, "Work-study Alternation" and "Production-education Integration" in the Training of IE Talents. We should establish a practice teaching system, constantly update and optimize the content of practice teaching, and fully reflect the training [9] of students' autonomous learning ability and IE ability; The school enterprise dual tutor mechanism is established to guide the students' practice training together; Strengthen the IE practice, and promote the sharing of practical teaching platform. We use various resources to build university science park, University Entrepreneurship Park, business incubation base and small and micro entrepreneurial base, and set up a group of college students' IE practice base [10].

Using the "second classroom" as the Second Channel for the Training of Creative and Entrepreneurial Talents. The "second classroom" is an effective carrier [7] for IE education. By carrying out the IE forum, training, academic lectures, to create an atmosphere of IE education, expand the horizons of students, cultivating the IE spirit. We will energetically support the academic community that uses the advantage of the discipline to encourage students to take the initiative in scientific research and innovative entrepreneurial activities. Through the "second classroom" discipline competition activities, we will achieve "promoting teaching through competition, promoting learning through competition, and promoting innovation by competition". We should actively promote the IE training and practice for college students, and constantly improve the training level of IE talents, and cultivate the soil of "mass entrepreneurship and innovation". Through discipline competition, we can promote the transformation of competition results and the combination of production, teaching and research. We should innovate and lead entrepreneurship, entrepreneurship and employment, and promote graduates' higher quality entrepreneurship and employment.

Construction of IE Teaching Staff in the Integration of engineering and Engineering. Increase the training of young teachers in efforts to gradually improve the teachers in high education, high professional title and high level proportion; professional teachers must according to 
the professional direction of part-time enterprise technicians and engineers to design a testing exercise, teachers can be a problem, a project into the enterprise practice; hire technical personnel of enterprises executives, works as a part-time teacher; actively carry out IE education teacher training, to master the knowledge, skills, entrepreneurship and IE education, construct the training teachers guarantee. Fig. 2 shows the ways of IE talents training.

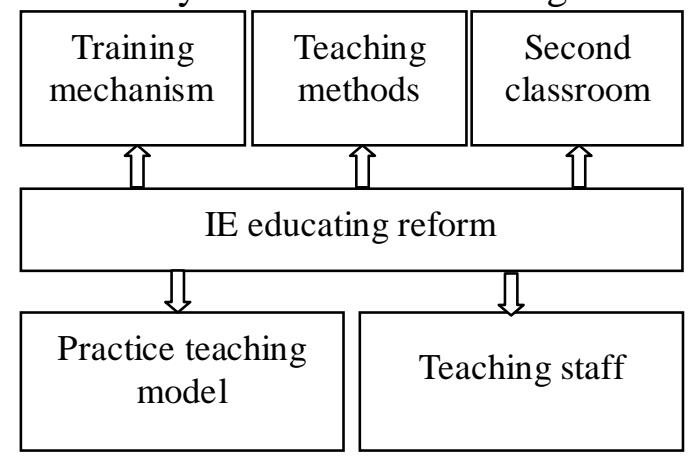

Figure 2. Ways of IE Talents Training

\section{Summary}

Through IE education, we encourage the public entrepreneurship and encourage college students to start their own businesses. This is an important measure for the country to activate the whole society's innovative vitality and improve the efficiency of financial investment, and it's a real feat of "saving the people". As a group of college students, we should be the participants and main force of Chinese social innovation and entrepreneurship, and should conform to the tide and embrace a rare "social development bonus". IE education is the direction of China's higher education reform. It should be the basic quality education for all college students. We should seize the opportunity of transformation in universities and explore the IE talent training mode, so that universities can truly become the source of training high-quality talents and promoting social progress.

\section{Acknowledgements}

2016 Jilin higher education teaching reform research topic: Research on IE education talent training mode of local University under transformation development background, -- take mechanical talent training as an example: Moderator: Yanhong Sun.

2017Jilin social science fund project: Research on the cooperative education mechanism and quality assurance and monitoring system of college and enterprise in Applied Universities in Jilin. Moderator: Yanhong Sun.

\section{Reference}

[1] D.G. Dong: Ability And Wisdom, Vol. 31(2017)No.11,p.77.

[2] J. Qin, X.Y. Wu: Industrial \& Science Tribune, Vol.15(2016)No.13,p.102.

[3] D.S. Liu: Education Review, (2016)No.11,p.88.

[4] J. Wang: Journal of Innovation and Enterprise Education, Vol. 7(2016)No.4,p.99.

[5] F.M. Shen, G.L. Xu: College Students' innovation and entrepreneurship course ( Higher Education Press, China 2014).

[6] X.M. Yang, W.L. Wang: Theory of Innovation and Entrepreneurship Education (Tsinghua University Press, China 2017).

[7] L.J. Jiang, M.Z. Gu: Chinese Vocational and Technical Education, (2016) No.10, p.71.

[8] L. Zhang, F.Q. Wang: Chinese Vocational and Technical Education,(2017) No.28, p.82.

[9] R. Zhang: Vocational Technology, Vol.16(2017)No.1,p.55.

[10] Q.L. Xie, Y. Cheng: Experimental Technology and Management, Vol.34(2017) No.12,p.196. 